\title{
Deep neck space abscesses of dental origin: the impact of Streptococcus group Milleri
}

\author{
Andrej Terzic · Paolo Scolozzi
}

Received: 12 August 2013/Accepted: 8 November 2013/Published online: 17 November 2013

(C) Springer-Verlag Berlin Heidelberg 2013

\begin{abstract}
In recent years, there has been rising interest in Streptococcus group Milleri (SM) because high mortality rates have been related to it. In case of deep neck infections (DNI), whatever the origin, mortality rates as high as $26 \%$ were reported. But there are no data available for DNI with SM of purely dental origin. The aim of our article was to describe and analyse DNI of purely dental origin involving on one hand SM and on the other hand infections without presence of SM. We compared these two groups and statistically investigated if there were differences in clinical presentation (age, mouth opening, length of hospital stay, laboratory parameters) or clinical behaviour (re-operation, re-hospitalisation, secondary osteomyelitis, stay at intensive care, length of antibiotic treatment, presence of resistances against antibiotics, incapacity to work). For this, we retrospectively searched medical records of our institution for all purulent DNI treated from 2004 till 2012. We found 81 patients meeting all inclusion criteria. Thirtyfour patients had involvement of SM, 47 did not. The only statistically significant difference between the SM group and the non-SM group was the length of incapacity to work. All other parameters were non-significant. Furthermore, there were no fatalities. In conclusion, the clinical importance of this article is that patients with deep neck abscesses of purely dental origin involving SM do not need more or different care when compared to all other DNI of dental origin.
\end{abstract}

\footnotetext{
A. Terzic $(\varangle) \cdot$ P. Scolozzi

Service of Maxillo-Facial and Oral Surgery, Department of Surgery, Medical School, University of Geneva Hospitals (HUG), Rue Gabrielle-Perret-Gentil 4, 1211 Geneva 14, Switzerland e-mail: andrej.terzic@hcuge.ch
}

Keywords Deep neck infection - Deep neck abscess $\cdot$ Dental origin $\cdot$ Odontogenic $\cdot$ Streptococcus group Milleri

\section{Introduction}

In 1956, GUTHOF, a German microbiologist, discovered a new species of bacteria within the Streptococcus viridians organisms and he named it Streptococcus Milleri. This was to honour Willoughby D. Miller (1853-1907), an American dentist and the first oral microbiologist [1]. At present, the term Streptococcus group Milleri (SM) refers to a triad of bacteria consisting of Streptococcus anginosus, Streptococcus constellatus and Streptococcus intermedius [2-4]. These bacteria belong to the normal flora of human mucosa [2] and can be found all over the body. Streptococcus anginosus is more commonly encountered in the gastrointestinal and urinary tract, S. constellatus in the gastrointestinal or respiratory tract, while $S$. intermedius is mostly found in the head and neck [5]. Even though commensals, SM are associated with pyogenic infections $[2-4,6]$ and are said to lead to suppurative complications at a high rate [7].

In recent years, there has been rising interest in SM $[3,4,6,8]$. High mortality rates have been related to infections with SM, for instance for generalised bacteraemia with a mortality rate of $4 \%$ [3]. In case of deep neck infections, whatever the origin, mortality rates as high as $26 \%$ were reported [9], but there are no data available concerning infections with SM of purely dental origin. The aim of our article is to describe and analyse deep neck space abscesses (DNA) of dental origin for infections involving, on one hand, SM and, on the other, infections without the presence of SM and to compare 
these two groups. Statistical tests were performed to find differences in clinical presentation and behaviour.

\section{Materials and methods}

We retrospectively searched the medical records from 2004 until the end of 2012 of our department. We included patients meeting the following criteria:

- DNA with the presence of pus. Only abscesses located in the following spaces were included: masticator, buccal, sublingual, submandibular, parapharyngeal, carotid sheath, retropharyngeal, prevertebral and visceral space. These neck spaces are defined in more detail by Mukherji et al. [10]. Minor local dental abscesses within the vestibulum oris were excluded.

- The infection was of dental origin and the related tooth was identified.

- Surgical treatment with incision and drainage, extraoral and/or intraoral.

- The presence of bacteriological cultures for all patients.

By means of statistical software (PASW Statistics, version 18.0.0), we performed descriptive statistics for age, sex, the length of hospital stay, length of antibiotic treatment including hospital stay and post-hospitalisation time, presence of antibiotic resistances, the initial inflammatory parameters (full white blood cell count, $\mathrm{C}$-reactive protein, temperature measured in the eardrum), the initial mouth opening, complications (re-hospitalisation, re-operations, osteomyelitis, need for intensive care) and the total number of days with incapacity to work including hospital stay. Then all patients were stratified into an SM group and a non-SM group and the descriptive statistics were repeated. With a Mann-Whitney $U$ test, we analysed differences of results for the SM and non-SM group. A $p \leq 0.05$ was judged significant. We investigated antibiotic resistance and complications as an influencing factor with a Fisher exact test; a $p \leq 0.05$ was judged as significant. We also identified the antibiotics used during the hospital stay for the entire group and made an overview of the bacteria involved other than SM. Mortality was examined.

\section{Results}

The results for the entire patient group are summarised in Table $1.42 \%$ of all patients had an involvement of SM, while SM was absent in $58 \%$. Tables 2 and 3 show the results stratified for the SM and non-SM groups. The only statistically significant difference between the SM group and the non-SM group is the length of incapacity
Table 1 Overview of standard variables for all patients

\begin{tabular}{llrc}
\hline & $\begin{array}{l}\text { Number of } \\
\text { patients }\end{array}$ & Mean & $\begin{array}{c}\text { Standard } \\
\text { deviation }\end{array}$ \\
\hline Age in years & 81 & 41.9 & 18.7 \\
Length of hospital stay in days & 81 & 6.3 & 6.6 \\
$\begin{array}{l}\text { Length of antibiotic treatment in } \\
\quad 67\end{array}$ & 14.7 & 11.2 \\
$\quad$ days & 76 & 14.4 & 4.8 \\
White blood cell count in g/l & 61 & 151.8 & 125.8 \\
C-reactive protein in mg/l & 58 & 37.4 & 0.7 \\
$\begin{array}{l}\text { Temperature in }{ }^{\circ} \mathrm{C} \\
\text { Mouth opening in mm measured } \\
\text { between the incisors }\end{array}$ & 60 & 16.7 & 7.8 \\
\begin{tabular}{l} 
Incapacity to work in days \\
\hline
\end{tabular} & 40 & 17.1 & 7.7 \\
\hline
\end{tabular}

to work. All other parameters are deemed non-significant. The antibiotics administered are summarised in Table 4. Apart from SM, 28 different germs were found. The three most frequent were: Streptococcus alpha-haemolyticus $(10 \times)$, Staphylococcus epidermidis $(9 \times)$, and Parvimonas micra $(6 \times)$. Of the 28 germs, 16 were found only once. More details are displayed in Table 5. No patient succumbed due to the DNA with or without SM in the present study.

\section{Discussion}

The results show that there was no statistical difference in the clinical presentation (age, mouth opening, length of hospital stay), the laboratory parameters (C-reactive protein, full blood cell count, temperature) or the length of antibiotic treatment between patients with DNA of dental origin with or without the presence of SM. SM and non-SM patients are statistically not different regarding their potential for complications (re-operation, re-hospitalisation, secondary osteomyelitis), and the presence of resistances against antibiotics in the SM and non-SM group did not significantly alter the outcome. The only statistically significant difference between the SM group and the nonSM group is the length of incapacity to work. We do not have an explanation for this.

The present study also showed that the degree of severity of disease in DNA of dental origin is probably milder compared to other patient groups of other specialities or anatomical sites. In head and neck DNA (all aetiologies and germs confound), the available figures for mortality rates are scattered and include $0 \%$ [11], $0.3 \%$ [12], $0.65 \%$ [13], $0.8 \%$ [14], $1.6 \%$ [15] and $2.4 \%$ [9].There is also one study investigating DNA with SM with a $14 \%$ mortality rate, but it is based on only seven patients and therefore not completely reliable [4]. In our group with purely dental infections, no patient died due 
Table 2 Numeric standard variables for SM and non-SM patients

\begin{tabular}{llll}
\hline $\begin{array}{l}\text { Number of } \\
\text { patients }\end{array}$ & Mean & $\begin{array}{l}\text { Standard } \\
\text { deviation }\end{array}$ \\
\hline
\end{tabular}

Age in years

$\begin{array}{lllll}\text { SM } & 34 & 45.12 & 16.5 & 0.143 \\ \text { Non-SM } & 47 & 39.5 & 19.9 & \end{array}$

Length of hospital stay in days

$\begin{array}{llll}\text { SM } & 34 & 7.7 & 7.7 \\ \text { Non-SM } & 47 & 5.3 & 5.6\end{array}$

Length of antibiotic treatment in days

$\begin{array}{llrr}\text { SM } & 28 & 16.2 & 13.8 \\ \text { Non-SM } & 39 & 13.6 & 9.0\end{array}$

White blood cell count in $\mathrm{g} / \mathrm{l}$

$\begin{array}{lcccc}\text { SM } & 30 & 14.3 & 4.6 & 0.979 \\ \text { Non-SM } & 46 & 14.4 & 5.0 & \\ \begin{array}{l}\text { C-reactive } \\ \text { SM }\end{array} & 22 & & & \\ \text { Non-SM } & 39 & 177.9 & 126.4 & 0.117 \\ \text { Temperature in } & { }^{\circ} \mathrm{C} & 137.0 & 124.7 & \\ \text { SM } & 23 & & & \\ \text { Non-SM } & 35 & 37.4 & 0.8 & 0.577\end{array}$

Mouth opening in mm measured between the incisors

\begin{tabular}{lccrl} 
SM & 27 & 17.7 & 13.7 & \\
Non-SM & 33 & 15.8 & 9.0 & \\
Incapacity to & work in days & & & \\
SM & 18 & 20.5 & 7.8 & $0.010^{*}$ \\
Non-SM & 22 & 14.3 & 6.5 & \\
\hline
\end{tabular}

A Mann-Whitney $U$ test was performed to investigate statistically significant differences

* The significance level was $p \leq 0.05$

to DNA. This backs previous observations that in the head and neck, patients with DNA of purely dental origin heal better than DNA caused by any other aetiology $[16,17]$. In the present study this may also be influenced by the high availability of medical care and mandatory health insurance for the entire population in our country.

Although SM has gained interest in the last few years, publications for head and neck are rare and the number of published patients is rather low. The number of patients included in up-to-date available reports is 6 [9], 7 [4], 12 [18] and 17 [6] in adult cohorts and 16 in a paediatric cohort [8]. But in all these reports, the aetiologies and germs are heterogeneous. In contrast to this, in the present study the patient group is homogeneous. It includes only infections of purely dental origin: 34 of them with SM and 47 without. Given the absence of similar studies, an exact comparison with other published data was not possible.
Table 3 Categorical variables for SM and non-SM patients in $n=$ patients and $\%$ where appropriate

\begin{tabular}{|c|c|c|c|c|}
\hline & $\begin{array}{l}\text { For all } 81 \\
\text { patients (in } \%)\end{array}$ & $\begin{array}{l}\text { SM patients } \\
\text { (in \%) }\end{array}$ & $\begin{array}{l}\text { Non-SM } \\
\text { patients (in \%) }\end{array}$ & $p$ \\
\hline \multicolumn{5}{|l|}{ Sex } \\
\hline Female & $26(32.1)$ & $11(13.6)$ & $15(18.5)$ & \multirow[t]{2}{*}{-} \\
\hline Male & $55(67.9)$ & $23(28.4)$ & $32(39.5)$ & \\
\hline \multicolumn{5}{|c|}{ Re-hospitalisations } \\
\hline Yes & $6(7.4)$ & $3(3.7)$ & $3(3.7)$ & \multirow[t]{2}{*}{-} \\
\hline No & $75(92.6)$ & & & \\
\hline \multicolumn{5}{|c|}{ Stay at intensive care } \\
\hline Yes & $6(7.4)$ & $3(3.7)$ & $3(3.7)$ & \multirow[t]{2}{*}{-} \\
\hline No & $75(92.6)$ & & & \\
\hline \multicolumn{5}{|c|}{ Secondary osteomyelitis } \\
\hline Yes & $3(3.7)$ & $1(1.2)$ & $2(2.5)$ & \multirow[t]{2}{*}{-} \\
\hline No & $78(96.3)$ & & & \\
\hline \multicolumn{5}{|c|}{ Antibiotic resistances for the causing bacteria } \\
\hline Yes & $28(34.5)$ & $17(21.0)$ & $11(13.6)$ & \multirow[t]{3}{*}{0.21} \\
\hline No & $20(24.7)$ & $16(19.8)$ & $4(4.9)$ & \\
\hline Not tested & $33(40.8)$ & $1(1.2)$ & $32(39.5)$ & \\
\hline \multicolumn{5}{|c|}{ Complications (re-operations, osteomyelitis, intensive care) } \\
\hline Yes & $16(19.8)$ & $7(8.6)$ & $9(11.1)$ & \multirow[t]{2}{*}{1.0} \\
\hline No & $65(80.2)$ & $27(33.3)$ & $38(46.9)$ & \\
\hline
\end{tabular}

A Fisher exact test was performed to investigate statistically significant differences for the last two variables

Table 4 Antibiotics used in this study

\begin{tabular}{|c|c|c|c|c|}
\hline & Dose & Mode & $\begin{array}{l}\text { Number } \\
\text { of } \\
\text { patients }\end{array}$ & Percent \\
\hline $\begin{array}{l}\text { Amoxicillin/ } \\
\text { clavulanic acid }\end{array}$ & $\begin{array}{c}3 \times 1,000 / \\
200 \mathrm{mg}\end{array}$ & i.v. ${ }^{\mathrm{a}}$ & 61 & 75 \\
\hline Clindamycin & $3 \times 600 \mathrm{mg}$ & i.v. & 12 & 12 \\
\hline Imipenem/cilastin & $\begin{array}{l}4 \times 500 / \\
\quad 4 \times 500 \mathrm{mg}\end{array}$ & i.v. & 3 & 4 \\
\hline Amoxicillin & $3 \times 1,000 \mathrm{mg}$ & i.v. & 3 & 4 \\
\hline $\begin{array}{l}\text { Amoxicillin/ } \\
\text { clavulanic acid and } \\
\text { metronidazole }\end{array}$ & $\begin{array}{l}3 \times 1,000 / 200 \\
\text { and } \\
2 \times 500 \mathrm{mg}\end{array}$ & i.v. & 2 & 2 \\
\hline $\begin{array}{l}\text { Clindamycin and } \\
\text { metronidazole }\end{array}$ & $\begin{array}{l}3 \times 600 \text { and } \\
2 \times 500 \mathrm{mg}\end{array}$ & i.v. & 1 & 1 \\
\hline
\end{tabular}

The 12 patients who received clindamycin were all allergic to penicillin

a All antibiotics were given intravenously except for one patient (amoxicillin/clavulanic acid, $3 \times 500 / 125 \mathrm{mg}$ )

In conclusion, the clinical importance of this article is that maxillofacial patients with DNA of purely dental origin involving SM do not need more or different care when compared with all other DNA of dental origin. 
Table 5 Bacteria other than SM found in this study

\begin{tabular}{|c|c|}
\hline Bacteria & Found in testing \\
\hline Streptococcus alpha-haemolyticus & 10 \\
\hline Staphylococcus epidermidis & 9 \\
\hline Parvimonas micra & 6 \\
\hline Candida albicans & 5 \\
\hline Streptococcus mitis & 4 \\
\hline Fusobacterium sp. & 4 \\
\hline Slackia exigua & 3 \\
\hline Staphylococcus coagulase-negative & 3 \\
\hline Streptococcus massiliensis & 2 \\
\hline Escherichia coli & 2 \\
\hline Haemophilus influenzae & 2 \\
\hline Enterococcus faecalis & 2 \\
\hline Staphylococcus capitis & 1 \\
\hline Candida glabrata & 1 \\
\hline Streptococcus peroris & 1 \\
\hline Prevotella buccae & 1 \\
\hline Eikenella corrodens & 1 \\
\hline Neisseria sp. & 1 \\
\hline Pseudomonas aeruginosa & 1 \\
\hline Streptococcus sanguinis & 1 \\
\hline Streptococcus beta-hemolyticus group C & 1 \\
\hline Corynnebacterium & 1 \\
\hline Streptococcus parasanguinis & 1 \\
\hline Lactobacillus gasseri & 1 \\
\hline Bacteroides heparinolyticus & 1 \\
\hline Prevotella intermedia & 1 \\
\hline Veilonella parvula & 1 \\
\hline Propionibacterium acnes & 1 \\
\hline
\end{tabular}

Acknowledgments We wish to thank Christophe Combescure (Centre of Clinical Research and Division of Clinical Epidemiology, Department of Health and Community Medicine, University Hospitals and Faculty of Medicine, Geneva, Switzerland) for cross-checking the statistics.

Conflict of interest The authors declare that they have no conflict of interest.

\section{References}

1. Guthof O (1956) Ueber pathogene "vergrünende Streptokokken”. Zbltt Bakteriol 166:553-565
2. Gossling J (1988) Occurrence and pathogenicity of the Streptococcus Milleri group. Rev Infect Dis 10:257-285

3. Bert F, Lancelin MB, Zechovsky NL (1998) Clinical significance of bacteremia involving the "Streptococcus milleri" group: 51 cases and review. Clin Infect Dis 27:385-387

4. Foxton CR, Kapila S, Kong J, Thomson NJ (2012) Streptococcus milleri head and neck abscesses: a case series. Ear Nose Throat J 91:246-254

5. Jacobs JA, Pietersen HG, Stobberingh EE, Soeters PB (1995) Streptococcus anginosus, Streptococcus constellatus and Streptococcus intermedius: clinical relevance, hemolytic and serologic characteristics. Am J Clin Path 104:547-553

6. Hirai T, Kimura S, Mori N (2005) Head and neck infections caused by Streptococcus milleri group: an analysis of 17 cases. Auris Nasus Larynx 32:55-58

7. Murray HW, Gross KC, Masur H, Roberts RB (1978) Serious infections caused by Streptococcus milleri. Am J Med 64:759-764

8. Han JK, Kerschner JE (2001) Streptococcus milleri: an organism for head and neck infections and abscess. Arch Otolaryngol Head Neck Surg 127:650-654

9. Bottin R, Marioni G, Rinaldi R, Boninsegna M, Salvadori L, Staffieri A (2003) Deep neck infection: a present-day complication. A retrospective review of 83 cases (1998-2001). Eur Arch Otorhinolaryngol 260:576-579

10. Mukherji SK, Castillo M (1998) A simplified approach to the spaces of the suprahyoid neck. Rad Clin North Am 36:761-780

11. Daramola OO, Flanagan CE, Maisel RH, Odland RM (2009) Diagnosis and treatment of deep neck space abscesses. Otolaryngol Head Neck Surg 141:123-130

12. Boscolo-Rizzo P, Stellin M, Muzzi E, Mantovani M, Fuson R, Lupato V, Trabalzini F, Da Mosto MC (2012) Deep neck infections: a study of 365 cases highlighting recommendations for management and treatment. Eur Arch Otorhinolaryngol 269:1241-1249

13. Wong TY (1999) A nationwide survey of deaths from oral and maxillofacial infections: the Taiwanese experience. J Oral Maxillofac Surg 57:1297-1299

14. Lee YQ, Kanagalingam J (2011) Deep neck abscesses: the Singapore experience. Eur Arch Otorhinolaryngol 268:609-614

15. Huang TT, Liu TC, Chen PR, Tseng FY, Yeh TH, Chen YS (2004) Deep neck infection: analysis of 185 cases. Head Neck 26:854-860

16. Flynn TR, Shanti RM, Hayes C (2006) Severe odontogenic infections, part 2: prospective outcomes study. J Oral Maxillofac Surg 64:1104-1113

17. Lee JK, Kim HD, Lim SC (2007) Predisposing factors of complicated deep neck infection: an analysis of 158 cases. Yonsei Med J 48:55-62

18. Jankowska B, Salami A, Cordone G, Ottoboni S, Mora R (2003) Deep neck space infections. Int Congr Ser 1240:1497-1500 